\title{
Obstacles to the Implementation of Mixed Operation in China's Financial Industry
}

\author{
Hu Xiaohuan \\ Shaanxi Normal University \\ Xi'an, China \\ 1558080921@qq.com
}

\begin{abstract}
Finance is an important part of the national economy. Under the background of economic globalization, it is one of the core tasks for national government to establish a stable and safe financial system. After the founding of the People's Republic of China, China has now formed a financial regulatory structure under the supervision of "one line and two sessions" with decades of development. However, with the continuous opening up and continuous innovation of China's financial industry, China's original financial supervision mechanism has not adapted to the development of China's current finance, and mixed operation has become a normal state. There are many obstacles to the complete transformation from separate operation to mixed operation. This paper attempts to find some obstacles such as imperfect financial supervision system, the legal environment that is not conducive to reform, and the risk management method under complex conditions. China's adaptive financial supervision model is explored to make recommendations for further improving the financial market.
\end{abstract}

Keywords-Financial industry; Mixed operation; Separate operation

\section{INTRODUCTION}

\section{A. Research Background}

China's financial industry has experienced a transition from separate operations to mixed operations and once again to separate operations. In recent years, the domestic call for mixed business in the financial industry has begun to appear and is getting higher and higher, mainly driven by two reasons: Internationally, the US subprime mortgage crisis triggered a global crisis in 2008. Many scholars believe that under the separate supervision mode, the supervision work of various industries is separated. The avoidance attitude of various supervisory authorities leads to a regulatory vacuum, so the risk crosses and eventually leads to a big crisis; In China, under the separate supervision mode, the resources between China's financial institutions cannot be effectively utilized, resulting in inefficiency and the disruption of financial products. The outbreak of the mid-year stock market crash is pushing the reform of mixed operations to the forefront. Scholars believe that the stock market disaster is a concentrated manifestation of the drawbacks of the separate supervision model.

In fact, China' $\mathrm{s}$ financial industry' $\mathrm{s}$ business model has become increasingly unable to meet current needs. On the one hand, separate operations limit the scope of financial institutions' business, which not only hinders resource sharing, but also limits the innovation of financial products. This in turn violates the original intention of diversifying risks and improving efficiency. On the other hand, different investors have different pursuits of risks and benefits, investment needs have become more diversified, and customers have become more and more popular with one-stop financial services. The strict separation of banking, securities and insurance businesses has made it difficult for customers to meet their needs. The above two needs highlight the need for China to gradually implement mixed operations.

Mixed operation has many advantages in improving financial efficiency, diversifying risks and rationally allocating resources. Implementing mixed operation is one of the ultimate goals of China's financial reform. However, there are many obstacles to this reform. This paper attempts to find out the obstacles., and try to give advice to solve these obstacles.

\section{B. Literature Review}

There have been many discussions about the implementation of mixed operation in China's financial industry. Some scholars have discussed whether China's financial industry should conduct discussions on mixed management reform. Yiyao Cui ${ }^{[1]}(2009)$ shows concerns about regulatory issues and risk management issues in mixed operations, pointing out that China's mixed operation reform needs to be cautious and cannot be blindly promoted. Shasha $\mathrm{Liu}^{[2]}(2017)$ points out that although there are many obstacles to the reform of mixed operation, whether it is from the response to foreign markets or domestic development needs, financial industry mixed operation is imperative.

There are also many scholars who believe that China's financial industry should carry out mixed management reforms and give ideas for promoting reforms. Jiangang Peng ${ }^{[3]}(2014)$ proposes that China's mixed operation reform can be carried out in two steps: first establish a mixed operation system and legal framework, and then focus on strengthening risk supervision; By studying the precedents of mixed management reforms in the United States, Japan, and South Korea, Heli Wang $^{[4]}(2008)$ points out that China's mixed operation reform can learn from the model of US financial holding companies. Lijun $\mathrm{Wu}^{[5]}(2012)$ studied the precedents of reforms in other countries in the world and gave a choice of the regulatory path for China's mixed operation reform 


\section{CURRENT STATUS OF CHINA'S FINANCIAL INDUSTRY}

Before 2018, China's financial industry adopted a model of separate supervision, which was managed by the People's Bank of China ${ }^{[6]}$. The supervisory authorities separately supervised their respective fields and did not interfere with each other. In March 2018, the China Insurance Regulatory Commission and the China Banking Regulatory Commission merged into the Bank of China Insurance Regulatory Commission, the Banking Insurance Regulatory Commission. After the merger, the supervision work of various industries is still separate. Therefore, the following is still divided into the banking industry, the securities industry, and the insurance industry

\section{A. Current status of banking industry}

With the acceleration of China's interest rate marketization process, the impact on the banking industry has also become more and more serious, and it has suffered from the current situation of winter.

First, the growth rate of net profit has been in a downward trend in recent years. According to relevant information, aftertax net profit and asset profit margin of China's banking industry has been in decline since 2013.Recently, the China Banking Regulatory Commission has just released the main regulatory indicators of the banking industry in the second quarter of 2018.The data shows that in the first half of 2018, the accumulated net profit of commercial banks increased by $6.37 \%$ year-on-year, and the growth rate decreased by 1.55 percentage points compared with the same period of last year. Second, in terms of non-performing loans, the banking industry is not in good shape. Table 1 shows the status of nonperforming loan ratios of China's banking financial institutions in the past four years. It can be seen from the table that the nonperforming loan ratio is increasing year by year.

TABLE I NON-PERFORMING LOAN RATIO OF CHINA'S BANKING FINANCIAL INSTITUTIONS

\begin{tabular}{|c|c|c|c|c|c|}
\hline \multicolumn{5}{|c|}{ Non-performing loan ratio of China's banking financial institutions } \\
\hline Year & 2013 & 2014 & 2015 & 2016 & 2017 \\
\hline Rate & $0.95 \%$ & $1 \%$ & $1.29 \%$ & $1.67 \%$ & $1.71 \%$ \\
\hline
\end{tabular}

B. Current status of securities industry

China's securities industry started late. Since the establishment of the Shanghai Stock Exchange in 1990 and the establishment of the Shenzhen Stock Exchange in 1991, the development of China's securities industry has begun to formally develop. As China's opening up has deepened, the ranks of China's securities industry have become stronger and stronger. As of the end of 2017, there were 131 securities companies in China, and 30 brokers listed in 2017.From the perspective of business conditions, China' $\mathrm{s}$ securities industry has shown two development trends in the past two years. On the one hand, the brokerage business that acts as a proxy for securities trading has declined in scale, and the securities industry is highly competitive. According to data from the China Securities Industry Association, the net income of brokerage business of securities companies in 2017 was 82.092 billion yuan, a year-on-year decrease of $22.04 \%$.The overall commission of the industry has been declining in the past three years, and has even approached the operating profit and loss point. In 2017, the industry average commission rate was further reduced to $0.0378 \%$.On the other hand, in recent years, the income of the asset management business of the securities industry has continued to grow. According to the China Securities Industry Association, the business income of securities companies continued to grow in 2017. The annual net income reached 31.021 billion yuan, a year-on-year increase of $4.64 \%$, which also indicates the improvement of the invest.

\section{Insurance business status}

There are three main characteristics in the development of China's insurance industry. First, premium income continues to grow, but growth rate is falling. As shown in Table 2-2,in the past five years, the total assets of the industry have increased from 5.99 trillion yuan to 15.2 trillion yuan, and the total assets have been greatly improved. The growth rate has increased year by year since 2013, and there has been a significant slowdown in 2017.

Second, insurance density still has a big gap compared with international. Insurance density refers to the average premium of the resident population in a region. The data shows that the premium density in China has remained at 150-290 USD/person/year in the past five years, while the average level of the global insurance industry reached US\$605/person in 2010. / Every year, and continues to rise, this gap indicates that China's insurance industry is still at a low level.

Third, the homogenization of insurance products is serious. The products and services provided by major insurance companies are basically not much different. The marketing model and management model are also the same. They lack the products of independent innovation. As people's demand for insurance products increases, such homogenization may not satisfy people. The investment needs of the insurance company are also weakened to some extent.tment level of China's securities industry. 
TABLE II ORIGINAL PREMIUM INCOME GROWTH RATE

\begin{tabular}{|c|c|c|c|c|c|}
\hline \multicolumn{6}{|c|}{ Non-performing loan ratio of China's banking financial institutions } \\
\hline 2013 & 2014 & 2015 & 2016 & 2017 \\
\hline $0.95 \%$ & $1 \%$ & $1.29 \%$ & $1.67 \%$ & $1.71 \%$ \\
\hline Non-performing loan ratio of China's banking financial institutions \\
\hline 2013 & 2014 & 2015 & 2016 & 2017 \\
\hline $0.95 \%$ & $1 \%$ & $1.29 \%$ & $1.67 \%$ & $1.71 \%$ \\
\hline Non-performing loan ratio of China's banking financial institutions \\
\hline 2013 & 2014 & 2015 & 2016 & 2017 \\
\hline $0.95 \%$ & $1 \%$ & $1.29 \%$ & $1.67 \%$ & $1.71 \%$ \\
\hline \multicolumn{7}{|c|}{ Original premium income growth rate } \\
\hline Year & 2013 & 2014 & 2015 & 2016 & 2017 \\
\hline Rate & $11.2 \%$ & $17.49 \%$ & $20 \%$ & $27.5 \%$ & $18.16 \%$ \\
\hline Non-performing loan ratio of China's banking financial institutions \\
\hline 2013 & 2014 & 2015 & 2016 & 2017 \\
\hline $0.95 \%$ & $1 \%$ & $1.29 \%$ & $1.67 \%$ & $1.71 \%$ \\
\hline Non-performing loan ratio of China's banking financial institutions \\
\hline 2013 & 2014 & 2015 & 2016 & 2017 \\
\hline $0.95 \%$ & $1 \%$ & $1.29 \%$ & $1.67 \%$ & $1.71 \%$ \\
\hline
\end{tabular}

\section{OBSTACLES TO THE IMPLEMENTATION OF MIXED OPERATIONS IN THE FINANCIAL INDUSTRY}

\section{A. Financial supervision system is not perfect}

As the trend of mixed operations becomes more and more obvious, the business distribution and business structure of the financial industry will undergo tremendous changes, and the financial environment will become more complicated. Without a sound regulatory system, the funds of various financial institutions will be arbitrarily diverted. Not only will it lead to inefficient resource allocation, but it will also bring financial system risks in a serious way, affecting the sustained and stable development of the financial industry. However, at present, the current regulatory system cannot meet the requirements of mixed operation, mainly reflected in the lag of the development of the financial supervision system. Since virtually all businesses in the financial industry have already experienced mixed operations, the regulatory system has not accompanied the development of such mixed operations. The inherent incompatibility of the regulatory system has led to the coexistence of multiple regulatory and regulatory gaps. In terms of bullish supervision, taking China's bond market as an example, China's bond market is currently divided into interbank and exchange bond markets. Banks are regulated by the central bank, while exchanges are regulated by the CSRC. In addition to this, there are the National Development and Reform Commission, the China Banking Regulatory Commission, and the China Insurance Regulatory Commission. Then, in the event of disagreement, who is the regulator of the dominant bond market becomes a problem. For this reason, the real innovation in the bond market has not increased much in recent years. The only increase is the bond issuance and various terms and options embedded in the bond. At the same time, the "firewall" setting problem between different businesses and the mutual investment problem between different types of businesses are still in a blank state, which restricts the good development of mixed operations.

\section{B. Legal environment}

The law regulates investors' investment activities through its unique universal binding force. It is the most powerful weapon to maintain the stability of the financial system and the vigorous development of the financial industry. It is also a tool to defend the rights and interests of investors. There are two main problems in China's existing financial industry laws that hinder mixed operations. On the one hand, For a long time, China's financial industry has been divided into separate businesses. The corresponding laws have also been formed on this basis. The overlapping of business and the blind spots of business in financial supervision are equally legal, but there is no relevant law to restrict these problems. On the other hand, problems with non-compliance and lax enforcement still exist. When it comes to legal issues, we can only pay attention to the legislative aspects. Therefore, we have always been tasked with establishing and improving the legal system. However, if the established laws are not strictly observed and implemented, the harm may be greater than the lack of sound laws. After the implementation of comprehensive mixed operations, the financial environment will be more complicated, and the risks will be more difficult to control. If the risk of mixed operations is not fully estimated and prepared in law, it may be difficult to ensure the orderly development of the financial industry.

\section{Risk management}

In the mixed operation mode, there will be a variety of business cross-operations. A financial institution can operate all financial businesses, and the lack of identification of risks by financial institutions can lead to many unknown risks. If the risk of mixed operation is insufficient, it will rush into the road of mixed operation. The risk communication within the financial enterprise cannot be effectively controlled, which will lead to greater financial risks. Under mixed operations, when a financial institution makes a related transaction with other companies, when a risk arises, it is very easy to spread quickly and affect the related parties internally, triggering multiple financial leverage risks and the risk of related transactions.

\section{COUNTERMEASURES TO SOLVE THE OBSTACLES OF MIXED OPERATION}

\section{A. Improve the regulatory system}

The supervision system can learn from the change process of the mixed operation in the United States, that is, adopt the model of financial holding company, and supervise the financial holding company at the national level and local level, and its sub-industry, securities sub-industry and insurance subindustry The function of the regulatory agency to supervise, and each seed industry is supervised by multiple regulatory agencies, eventually forming a "double-layered" umbrella regulatory mechanism. 


\section{B. Establish and improve the legal system}

In law, the first is to eliminate the borders of securities, banks, insurance and various financial institutions through legislation, that is, legally affirm the mixed business model, and clear the institutional obstacles for the development of mixed operations. The second is to make up for the legal gap, clarify the overlapping areas, and establish a legal supervision system with clear responsibilities.

In law enforcement, a highly authoritative legal regulatory body should be established to regulate the enforcement of law enforcement agencies.

\section{Strengthen risk management}

First, the minimum requirements for risk management should be improved, especially for the management of concentrated risks, to avoid excessive risk exposure and to expose assets to additional risks. In addition, we must pay attention to the management of liquidity risk. On this issue, risk stress testing should be done by every organization. Second, increase the innovation of financial products, whether it is to carry out financial transaction system innovation or financial technology innovation, to meet the needs of investors to manage investment risks, to achieve the purpose of diversifying risks. Third, strengthen cooperation with international regulation.

\section{CONCLUSION}

At present, China's overall financial environment is very good. From the perspective of the development requirements of the financial industry and the needs of customers for diversified financial services, the current business model cannot meet the current financial needs, and the current financial industry's separate operating system hinders. With the development of the financial industry in a better direction, China's financial industry business model is in urgent need of reform. Implementing mixed operation is one of the ultimate goals of China's financial reform. However, there are many obstacles to this reform: the financial supervision system is imperfect, the legal environment is not conducive to reform, and the risk management methods under complicated conditions are resolved. These obstacles are not a day's work, but they can still learn from the precedent of the US mixed-use reform, that is, the reform of the financial holding company model. On this basis, solve the regulatory problems and build a sound legal system, and improve the risk management level. China's financial industry will certainly serve the real economy more efficiently.

\section{REFERENCES}

[1] Cui Yiyao. Reflections on the Implementation of Mixed Operation in China's Financial Industry under the Background of Financial Crisis[J]. Hainan Finance, 2009(01): 75-79.

[2] Liu Shasha, Yan Wei. Research on the Mixed Operation of China's Financial Industry in the New Era[J]. Think Tank Era, 2017(17): 278.

[3] Peng Jiangang, Zou Ke, Jiang Da. The Impact of Mixed Operation on Systematic Risks in Financial Industry and the Reform of China's Banking Business Model[J]. China Management Science,2014,22(S1):272-280.

[4] Wang Heli. Research on the Prospect of Financial Mixed Operation in China[J].Financial Research,2008(09):188-197.

[5] Wu Lijun. China's Financial Supervision System under Mixed Operation: International Comparison and Path Selection[J]. Teaching and Research, 2012(08): 33-39.

[6] Chen Xiangmei, Zhang Wei. Study on China's Financial Management Model and Path Selection[J]. Modern Economic Information,2017(17):278. 